University of Wollongong

Research Online

Australian Institute for Innovative Materials -

Papers

Australian Institute for Innovative Materials

$1-1-2018$

Decomposition Mechanism of Zinc Ammine Borohydride: A First-Principles Calculation

Xiaowei Chen

Fudan University, chenx@nju.edu.cn

Weidong Zou

Jimei University

Renquan Li

Jimei University

Guanglin Xia

University of Wollongong, guanglin@uow.edu.au

Xuebin Yu

Fudan University, xyu@uow.edu.au

Follow this and additional works at: https://ro.uow.edu.au/aiimpapers

Part of the Engineering Commons, and the Physical Sciences and Mathematics Commons

Research Online is the open access institutional repository for the University of Wollongong. For further information contact the UOW Library: research-pubs@uow.edu.au 


\title{
Decomposition Mechanism of Zinc Ammine Borohydride: A First-Principles Calculation
}

\author{
Abstract \\ The decomposition mechanism of zinc ammine borohydride ([Zn(NH 3 ) 2$][\mathrm{BH} 4] 2)$ has been studied by \\ density functional theory calculation. The release of $\mathrm{B} 2 \mathrm{H} 6$ and $\mathrm{BH} 3$ is predicted to be kinetically and/or \\ thermodynamically unfavorable for $[\mathrm{Zn}(\mathrm{NH} 3) 2][\mathrm{BH} 4] 2$, in agreement with experimental results that no \\ boranes were detected during decomposition. The climbing image nudged elastic band calculation and \\ ab initio molecular dynamics simulations indicate the formation of $\mathrm{NH} 3 \mathrm{BH} 3$ and $\mathrm{B} 2 \mathrm{H} 7$ - intermediates \\ during decomposition of [ $\mathrm{Zn}(\mathrm{NH} 3) 2][\mathrm{BH} 4] 2$, which is different from that observed for other reported \\ ammine metal borohydrides. The dehydrogenation occurs through reaction pathways involving transfer of \\ hydrides from the $\mathrm{Zn}$ cation to $\mathrm{BH} 4$ - or transfer of protons from $\mathrm{NH} 3 \mathrm{BH} 3$ to $\mathrm{NH} 3$.

\section{Disciplines \\ Engineering | Physical Sciences and Mathematics}

\section{Publication Details} \\ Chen, X., Zou, W., Li, R., Xia, G. \& Yu, X. (2018). Decomposition Mechanism of Zinc Ammine Borohydride: A \\ First-Principles Calculation. The Journal of Physical Chemistry C: Energy Conversion and Storage, Optical \\ and Electronic Devices, Interfaces, Nanomaterials, and Hard Matter, 122 (8), 4241-4249.
}




\section{Decomposition Mechanism of Zinc Ammine Borohydride: A First-Principles}

\section{Calculation}

Xiaowei Chen ${ }^{a b^{*}}$, Weidong Zou ${ }^{c}$, Renquan $\mathrm{Li}^{a}$, Guanglin Xia ${ }^{d}$, Xuebin Yu ${ }^{b *}$

${ }^{a}$ Department of Physics, School of Science, Jimei University, Xiamen, 361021, China

${ }^{b}$ Department of Materials Science, Fudan University, Shanghai 200433, China

${ }^{c}$ College of Physics and Electromechanical Engineering, Longyan University, Fujian, 364012 ,China

${ }^{d}$ Institute for Superconducting and Electronic Materials, University of Wollongong, North Wollongong, NSW, Australia

* To whom correspondence should be addressed.

E-mail: chenxiaowei@jmu.edu.cn

yuxuebin@fudan.edu.cn 


\begin{abstract}
The decomposition mechanism of zinc ammine borohydride $\left(\left[\mathrm{Zn}\left(\mathrm{NH}_{3}\right)_{2}\right]\left[\mathrm{BH}_{4}\right]_{2}\right)$ has been studied by density functional theory calculation. The release of $\mathrm{B}_{2} \mathrm{H}_{6}$ and $\mathrm{BH}_{3}$ is predicted to be kinetically and/or thermodynamically unfavorable for $\left[\mathrm{Zn}\left(\mathrm{NH}_{3}\right)_{2}\right]\left[\mathrm{BH}_{4}\right]_{2}$, in agreement with experimental results that no boranes were detected during decomposition. The climbing image nudged elastic band calculation and ab initio molecular dynamics simulations indicate the formation of $\mathrm{NH}_{3} \mathrm{BH}_{3}$ and $\mathrm{B}_{2} \mathrm{H}_{7}^{-}$ intermediates during decomposition of $\left[\mathrm{Zn}\left(\mathrm{NH}_{3}\right)_{2}\right]\left[\mathrm{BH}_{4}\right]_{2}$, which is different from that observed for other reported ammine metal borohydrides. The dehydrogenation occurs through reaction pathways involving transfers of hydrides from the $\mathrm{Zn}$ cation to $\mathrm{BH}_{4}{ }^{-}$or transfers of protons from $\mathrm{NH}_{3} \mathrm{BH}_{3}$ to $\mathrm{NH}_{3}$.
\end{abstract}




\section{Introduction}

Hydrogen is an ideal clean energy carrier because of its abundance, high heating value per mass and environmentally friendly product of water. ${ }^{1-3}$ Developing hydrogen storage materials with high gravimetric hydrogen densities and favorable de-hydrogenation/re-hydrogenation properties is one of the key challenges in using hydrogen as an alternative energy source for mobile or stationary applications. ${ }^{2}$ Metal borohydrides $\left(\mathrm{M}\left(\mathrm{BH}_{4}\right)_{x}\right)$ with high gravimetric and volumetric densities of hydrogen have received great attention in the past few decades. ${ }^{4-8}$ The experimental and theoretical studies suggest a correlation between the hydrogen desorption temperature and the Pauling electronegativity of the cation $\left(\chi_{\mathrm{p}}\right)$ of metal borohydrides. ${ }^{9,} 10$ The metal borohydrides with low $\chi_{\mathrm{p}}$ tend to release hydrogen at high temperature. For instance, $\mathrm{NaBH}_{4}, \mathrm{LiBH}_{4}$ and $\mathrm{Mg}\left(\mathrm{BH}_{4}\right)_{2}$ with $\chi_{\mathrm{p}}$ lower than 1.3 start to release $\mathrm{H}_{2}$ at temperature above $300{ }^{\circ} \mathrm{C} .{ }^{11-14}$ On the other hand, metal borohydrides with high $\chi_{\mathrm{p}}$ tend to release an undesired byproduct of diborane $\left(\mathrm{B}_{2} \mathrm{H}_{6}\right)$ at low temperatures. For example, $\mathrm{Al}\left(\mathrm{BH}_{4}\right)_{3}$ and $\mathrm{Zn}\left(\mathrm{BH}_{4}\right)_{2}$ with $\chi_{\mathrm{p}}$ of 1.6 and 1.65 , respectively, are volatile at room temperature and release a significant volume of $\mathrm{B}_{2} \mathrm{H}_{6}$ byproduct upon heating. ${ }^{8,15,16}$

The use of $\mathrm{NH}_{3}$ ligands to saturate and immobilize the metal cation with formation of ammine metal borohydrides $\left(\mathrm{AMBs},\left[\mathrm{M}\left(\mathrm{NH}_{3}\right)_{x}\right]\left[\mathrm{BH}_{4}\right]_{y}\right)$ is an effective strategy to improve thermo-dynamic stability of metal borohydrides. ${ }^{17-32}$ Although AMBs show improvement of dehydrogenation properties and prevention of $\mathrm{B}_{2} \mathrm{H}_{6}$ release compared to metal borohydrides, many of these AMBs tend to release ammonia during thermal decomposition. It has been reported that $\left[\mathrm{Li}\left(\mathrm{NH}_{3}\right)_{x}\right]\left[\mathrm{BH}_{4}\right]$ and $\left[\mathrm{Ca}\left(\mathrm{NH}_{3}\right)_{x}\right]\left[\mathrm{BH}_{4}\right]_{2}(x=1,2$ and 4) release a significant amount of ammonia below $300{ }^{\circ} \mathrm{C}$ under dynamic situation. ${ }^{17}$, 19, 21 The $\left[\mathrm{Mg}\left(\mathrm{NH}_{3}\right)_{2}\right]\left[\mathrm{BH}_{4}\right]_{2}$ and $\left[\mathrm{Al}\left(\mathrm{NH}_{3}\right)_{6}\right]\left[\mathrm{BH}_{4}\right]_{3}$ mainly release hydrogen with a certain amount of ammonia detected during decomposition. ${ }^{23,33}$ Among these AMBs, zinc ammine borohydride, $\left[\mathrm{Zn}\left(\mathrm{NH}_{3}\right)_{2}\right]\left[\mathrm{BH}_{4}\right]_{2}$, shows favorable dehydrogenation properties in terms of hydrogen desorption temperature and purity of gas release. As 
reported in a previous literature study, $\left[\mathrm{Zn}\left(\mathrm{NH}_{3}\right)_{2}\right]\left[\mathrm{BH}_{4}\right]_{2}$ is able to release $8.9 \mathrm{wt} \%$ hydrogen below $115{ }^{\circ} \mathrm{C}$ within 15 min without concomitant release of undesirable gases such as ammonia and boranes. ${ }^{22}$

The dehydrogenation of some of the AMBs may be achieved through combining hydrides from $\left[\mathrm{BH}_{4}\right]^{-}$and protons from $\mathrm{NH}_{3}$, ultimately yielding amorphous metal boronitrides. ${ }^{19}$, 23-26, 34-36 The experimental observation of the formation of well-crystallized $\mathrm{Zn}$ during dehydrogenation indicates that the decomposition pathway of $\left[\mathrm{Zn}\left(\mathrm{NH}_{3}\right)_{2}\right]\left[\mathrm{BH}_{4}\right]_{2}$ is slightly different from those of the other reported AMBs, in which the metal cations in the dehydrogenated products are always bonded to the $\mathrm{BN}$ species. ${ }^{22}$ Although a previous report suggested the formation of the $\mathrm{NH}_{3} \mathrm{BH}_{3}$ intermediate, ${ }^{37}$ the dehydrogenation mechanism of $\left[\mathrm{Zn}\left(\mathrm{NH}_{3}\right)_{2}\right]\left[\mathrm{BH}_{4}\right]_{2}$ is still unclear. Therefore, a detailed study of the decomposition mechanism of $\left[\mathrm{Zn}\left(\mathrm{NH}_{3}\right)_{2}\right]\left[\mathrm{BH}_{4}\right]_{2}$ will provide useful insights for improving its dehydrogenation performance and offer guidelines for designing novel Zn-based ammine borohydrides for hydrogen storage.

Herein, the decomposition mechanism of $\left[\mathrm{Zn}\left(\mathrm{NH}_{3}\right)_{2}\right]\left[\mathrm{BH}_{4}\right]_{2}$ was studied by density functional theory (DFT) calculation. We performed climbing image nudged elastic band (CI-NEB) calculation and ab initio molecular dynamics (AIMD) simulations to illustrate that the dehydrogenation mechanism of $\left[\mathrm{Zn}\left(\mathrm{NH}_{3}\right)_{2}\right]\left[\mathrm{BH}_{4}\right]_{2}$ is different from those of other reported $\mathrm{AMBs}$ which release hydrogen via combining hydrides from $\left[\mathrm{BH}_{4}\right]^{-}$and protons from $\mathrm{NH}_{3}$. Our calculation indicates the formation of $\mathrm{NH}_{3} \mathrm{BH}_{3}$ and $\mathrm{B}_{2} \mathrm{H}_{7}^{-}$intermediates during decomposition of $\left[\mathrm{Zn}\left(\mathrm{NH}_{3}\right)_{2}\right]\left[\mathrm{BH}_{4}\right]_{2}$.

\section{Computational Method}

As reported in a previous literature study, the $\left[\mathrm{Zn}\left(\mathrm{NH}_{3}\right)_{2}\right]\left[\mathrm{BH}_{4}\right]_{2}$ crystallize in the orthorhombic structure with a space group of $P 2_{1}$ and cell parameters of $a=6.392(4) \AA$, $b=8.417$ (6) $\AA, c=6.388(4) \AA, \alpha=\gamma=90^{\circ}$ and $\beta=92.407(4)^{\circ} .{ }^{22}$ The geometric structure was optimized by DFT calculation as implemented in MedeA@VASP code ${ }^{38}$. To describe the weak van der Waals $\mathrm{H}^{+\ldots . .-} \mathrm{H}$ dihydrogen bonds, the optB86b-vdW functional ${ }^{39-41}$ was 
adopted for geometric optimization. The projector-augmented wave (PAW) approach was used to describe the electron-ion interactions ${ }^{42}$. Plane wave with kinetic energy cutoff of $400 \mathrm{eV}$ was used. The generalized gradient approximation (GGA) of Perdew-Burke-Ernzerhof (PBE) was adopted to describe the exchange and correlation of electronics $^{43,44}$. The Brillouin zone was sampled by Monkhorst-Pack $k$-point meshes ${ }^{45}$ with mesh point spacing less than $0.05 \AA^{-1}$. Structural relaxations of atomic positions were carried out until the residual forces on each atoms were less than $0.02 \mathrm{eV} \cdot \AA^{-1}$. The $\mathrm{NH}_{3}$ diffusion barriers and $\mathrm{H}_{2}$ formation barriers were estimated by using the climbing image nudged elastic band (CI-NEB) method $^{46,47}$ until the forces on each atoms were less than $0.02 \mathrm{eV} \cdot \AA^{-1}$.

The $\mathrm{NH}_{3}$ vacancy was created by removing one $\mathrm{NH}_{3}$ molecule from $2 \times 1 \times 2$ supercell of $\left[\mathrm{Zn}\left(\mathrm{NH}_{3}\right)_{2}\right]\left[\mathrm{BH}_{4}\right]_{2}$. The $\mathrm{NH}_{3}$ vacancy formation energy was estimated using the following equation:

$E_{c}=\left[E\left(\mathrm{Zn}-\mathrm{NH}_{3}\right)+E\left(\mathrm{NH}_{3}\right)\right]-E_{\text {total }}$

where $E_{\text {total }}$ is the total energy of $\left[\mathrm{Zn}\left(\mathrm{NH}_{3}\right)_{2}\right]\left[\mathrm{BH}_{4}\right]_{2} ; E\left(\mathrm{NH}_{3}\right)$ represents the energy of isolated $\mathrm{NH}_{3}$ molecule; and $E\left(\mathrm{Zn}-\mathrm{NH}_{3}\right)$ is the total energy of $\left[\mathrm{Zn}\left(\mathrm{NH}_{3}\right)_{2}\right]\left[\mathrm{BH}_{4}\right]_{2}$ after a $\mathrm{NH}_{3}$ molecule is removed. The positive energy of $E_{c}$ indicates that the creation of $\mathrm{NH}_{3}$ vacancy is an endothermic process, and the negative energy of $E_{c}$ indicates that the creation of $\mathrm{NH}_{3}$ vacancy is an exothermic process.

Previous differential scanning calorimetry and in-situ X-ray diffraction data suggested that $\left[\mathrm{Zn}\left(\mathrm{NH}_{3}\right)_{2}\right]\left[\mathrm{BH}_{4}\right]_{2}$ started to release hydrogen at temperature higher than its melting point. ${ }^{22}$ In other word, $\left[\mathrm{Zn}\left(\mathrm{NH}_{3}\right)_{2}\right]\left[\mathrm{BH}_{4}\right]_{2}$ undergoes a phase change from the solid state to viscous liquid before hydrogen released. Hence, the CI-NEB calculation of hydrogen formation energy and barrier were calculated by using a molecular model in which one formula unit of $\left[\mathrm{Zn}\left(\mathrm{NH}_{3}\right)_{2}\right]\left[\mathrm{BH}_{4}\right]_{2}$ was placed in a cubic cell with a lattice parameter of $20 \AA$. The formation of a $\mathrm{H}_{2}$ molecule was achieved by moving a proton and a hydride away from host $\mathrm{N}$ and $\mathrm{B}$ atoms to form a hydrogen molecule with the $\mathrm{H}-\mathrm{H}$ distance of 
$0.74 \AA$. All of the atoms in the cell were relaxed during geometry optimization.

The vibrational enthalpies are important to estimate the reaction barrier and enthalpies. Therefore, we further investigate the reaction barrier and enthalpies of these reactions by including the zero-point energy (ZPE) and vibrational enthalpy contributions. Phonons are calculated using the supercell force-constant method and the vibrational enthalpies are obtained by directly summing the calculated phonon frequencies.

$\mathrm{Ab}$ initio molecular dynamics simulations (AIMD) were performed to further examine the decomposition mechanism. We used a $2 \times 1 \times 2$ supercell of $\left[\mathrm{Zn}\left(\mathrm{NH}_{3}\right)_{2}\right]\left[\mathrm{BH}_{4}\right]_{2}$ which contains 152 atoms to prevent the spurious interactions between neighboring supercells. The canonical ensemble (NVT) following the Born-Oppenheimer (BO) implementation was adopted. The ionic equations of motion were integrated using the Nose-Hoover algorithm with a time step of $1.0 \mathrm{fs}$; deuterium mass was used for the hydrogen atom in order to enable a larger time step. The simulated system was initially equilibrated at a temperature of $300 \mathrm{~K}$ for $2 \mathrm{ps}$ (2 $000 \mathrm{steps})$. Then, the simulation temperature increased from $300 \mathrm{~K}$ to $3000 \mathrm{~K}$ uniformly over $40 \mathrm{ps}$ (40 000 steps). The high temperatures used in simulation allowed reactions to be observed within 40 ps. To analyze the fragments during the simulation, we used a bond length cut-off of $\sim 1.3$ times of the normal bond length.

\section{Results and Discussion}

\subsection{Formation and Diffusion of $\mathrm{NH}_{3}$ Vacancy}

The transport property of $\mathrm{NH}_{3}$ vacancy is crucial to the thermodynamics and kinetics of ammonia release or intermediate formation. To understand the microscopic dehydrogenation mechanism of $\left[\mathrm{Zn}\left(\mathrm{NH}_{3}\right)_{2}\right]\left[\mathrm{BH}_{4}\right]_{2}$, the formation and diffusion of $\mathrm{NH}_{3}$ were studied.

Our calculated formation energy of $\mathrm{NH}_{3}$ vacancy is $1.13 \mathrm{eV}$ for $\left[\mathrm{Zn}\left(\mathrm{NH}_{3}\right)_{2}\right]\left[\mathrm{BH}_{4}\right]_{2}$, which is $0.68 \mathrm{eV}$ lower than that of $\left[\mathrm{Mg}\left(\mathrm{NH}_{3}\right)_{2}\right]\left[\mathrm{BH}_{4}\right]_{2}$. In addition, as shown in Figure 1, the energy barrier of ammonia diffusion is calculated to be $0.96 \mathrm{eV}$ for $\left[\mathrm{Zn}\left(\mathrm{NH}_{3}\right)_{2}\right]\left[\mathrm{BH}_{4}\right]_{2}$. 
The activation energy $\left(E_{a}\right)$ for self-diffusion of ammonia (combining the vacancy formation energy with the diffusion energy barrier) is calculated to be $2.09 \mathrm{eV}$, comparable to that of $\left[\mathrm{Mg}\left(\mathrm{NH}_{3}\right)_{2}\right]\left[\mathrm{BH}_{4}\right]_{2}$. Our previous reports suggest that AMBs with low $E_{a}$ tend to release ammonia during decomposition. ${ }^{34,35}$ Ammonia was not detected during thermal decomposition of $\left[\mathrm{Zn}\left(\mathrm{NH}_{3}\right)_{2}\right]\left[\mathrm{BH}_{4}\right]_{2}$, unlike that of $\left[\mathrm{Mg}\left(\mathrm{NH}_{3}\right)_{2}\right]\left[\mathrm{BH}_{4}\right]_{2}$ which released a small amount of $\mathrm{NH}_{3}$ during decomposition. ${ }^{22,23}$ With a relatively low ammonia diffusion energy barrier of $0.96 \mathrm{eV}, \mathrm{NH}_{3}$ may be able to diffuse and involve in the formation of amorphous intermediate(s) before the dehydrogenation of $\left[\mathrm{Zn}\left(\mathrm{NH}_{3}\right)_{2}\right]\left[\mathrm{BH}_{4}\right]_{2}$, which prevents its release upon heating.

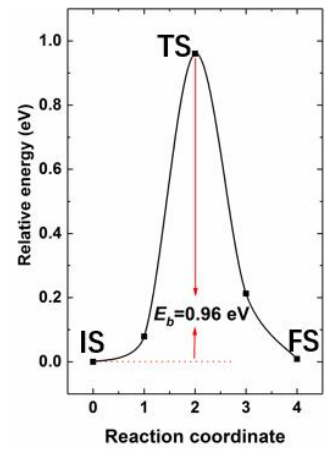

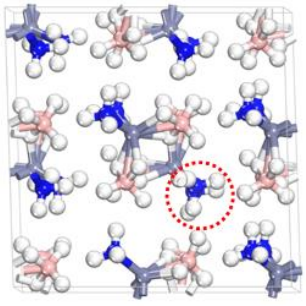

IS

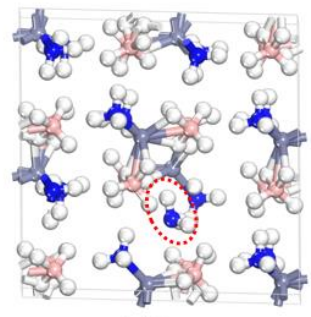

TS

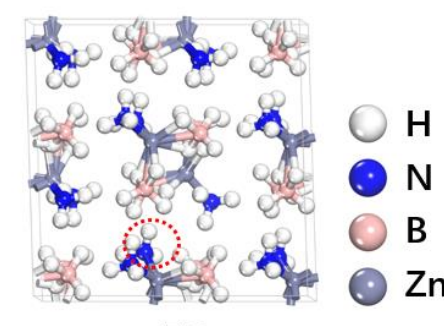

FS

Figure 1. Calculated energy barrier, and initial (IS), transition (TS) and final (FS) geometric structures of $\mathrm{NH}_{3}$ diffusion in $\left[\mathrm{Zn}\left(\mathrm{NH}_{3}\right)_{2}\right]\left[\mathrm{BH}_{4}\right]_{2} . E_{b}$ represents the calculated energy barrier.

\subsection{Direct Release of Hydrogen}




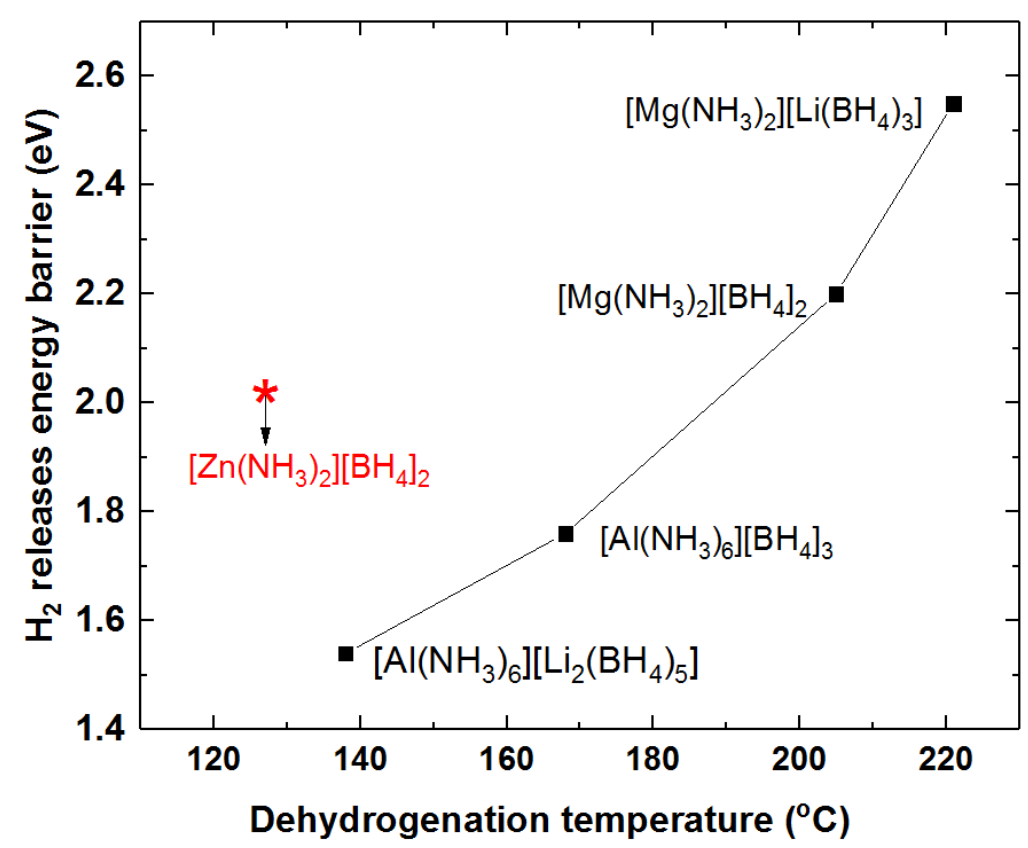

Figure 2. Calculated hydrogen release energy barriers for AMBs (via directly combining a hydride from $\mathrm{BH}_{4}{ }^{-}$and a proton from $\mathrm{NH}_{3}$ ) plotted as a function of experimental peak temperature of dehydrogenation. The experimental peak temperature of dehydrogenation is adapted from refs $22,23,26,33$ and 36 . The $\mathrm{H}_{2}$ releases energy barrier is adapted from refs 33 and 34 .

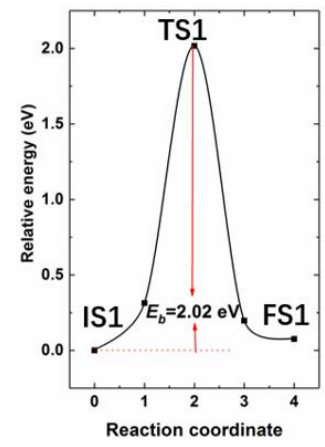

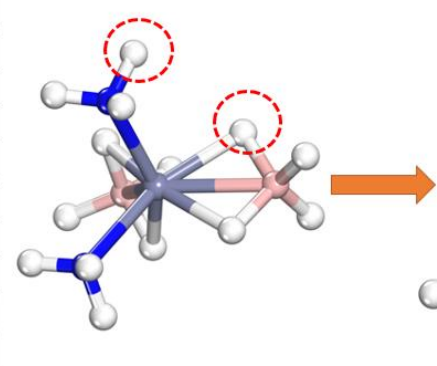

IS1

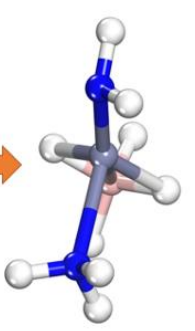

TS1
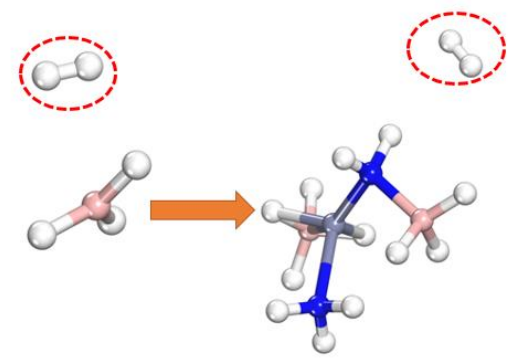

FS1

Figure 3. Calculated energy barrier, and initial (IS), transition (TS) and final (FS) geometric structures of $\mathrm{H}_{2}$ release from $\left[\mathrm{Zn}\left(\mathrm{NH}_{3}\right)_{2}\right]\left[\mathrm{BH}_{4}\right]_{2}$ via directly combine hydride from $\left[\mathrm{BH}_{4}\right]^{-}$and proton from $\mathrm{NH}_{3} . E_{b}$ represents the calculated energy barrier. 
Our previous studies about AMBs (seeing Figure 2) show a correlation between the peak dehydrogenation temperature and the calculated $\mathrm{H}_{2}$ release energy barrier $\left(\mathrm{H}_{2}\right.$ released via combining a hydride from $\mathrm{BH}_{4}{ }^{-}$and a proton from $\left.\mathrm{NH}_{3}\right) .{ }^{34,35}$ The AMBs with higher energy barriers tend to release hydrogen at higher temperatures. Therefore, we calculated a similar reaction pathway in which $\mathrm{H}_{2}$ is form via combining a hydride from $\mathrm{BH}_{4}{ }^{-}$and a proton from $\mathrm{NH}_{3}$. For making the discussion easier to understand, the reaction pathway was simplified as the following equation:

$\mathrm{BH}_{4}^{-}+\mathrm{NH}_{3} \rightarrow \mathrm{BH}_{3} \mathrm{NH}_{2}^{-}+\mathrm{H}_{2}$

As shown in Figure 3, the energy barrier of this process is $2.02 \mathrm{eV}$, which is $0.66 \mathrm{eV}$ higher than that of $\left[\mathrm{Al}\left(\mathrm{NH}_{3}\right)_{6}\right]\left[\mathrm{Li}_{2}\left(\mathrm{BH}_{4}\right)_{5}\right] .{ }^{35}$ The experimental results, however, show peak dehydrogenation temperature of 127 and $138{ }^{\circ} \mathrm{C}$ for $\left[\mathrm{Zn}\left(\mathrm{NH}_{3}\right)_{2}\right]\left[\mathrm{BH}_{4}\right]_{2}$ and $\left[\mathrm{Al}\left(\mathrm{NH}_{3}\right)_{6}\right]\left[\mathrm{Li}_{2}\left(\mathrm{BH}_{4}\right)_{5}\right]$, respectively. ${ }^{22}, \quad 33$ Thus, different from that of $\left[\mathrm{Al}\left(\mathrm{NH}_{3}\right)_{6}\right]\left[\mathrm{Li}_{2}\left(\mathrm{BH}_{4}\right)_{5}\right]$, the dehydrogenation of $\left[\mathrm{Zn}\left(\mathrm{NH}_{3}\right)_{2}\right]\left[\mathrm{BH}_{4}\right]_{2}$ may not through the direct combination of a proton from $\mathrm{NH}_{3}$ and a hydride from $\left[\mathrm{BH}_{4}\right]^{-}$. $\left[\mathrm{Zn}\left(\mathrm{NH}_{3}\right)_{2}\right]\left[\mathrm{BH}_{4}\right]_{2}$ presents an amorphous phase at $69^{\circ} \mathrm{C},{ }^{22}$, and with the temperature increase, some amorphous intermediate(s) may be formed.

\subsection{Formation of $\mathrm{B}_{2} \mathrm{H}_{6}$ or $\mathrm{BH}_{3}$}

The above discussion indicates that the formation of intermediate(s) may be a key aspect to uncover the dehydrogenation mechanism of $\left[\mathrm{Zn}\left(\mathrm{NH}_{3}\right)_{2}\right]\left[\mathrm{BH}_{4}\right]_{2}$. Previous experimental results show the release of $\mathrm{B}_{2} \mathrm{H}_{6}$ during decomposition of $\mathrm{Zn}\left(\mathrm{BH}_{4}\right)_{2}$. ${ }^{16}$ Although no borane byproducts were detected during the dehydrogenation of $\left[\mathrm{Zn}\left(\mathrm{NH}_{3}\right)_{2}\right]\left[\mathrm{BH}_{4}\right]_{2}$, the $\mathrm{B}_{2} \mathrm{H}_{6}$ or $\mathrm{BH}_{3}$ intermediate(s) may be formed before dehydrogenation, which may further react with $\mathrm{NH}_{3}$ to release hydrogen. 

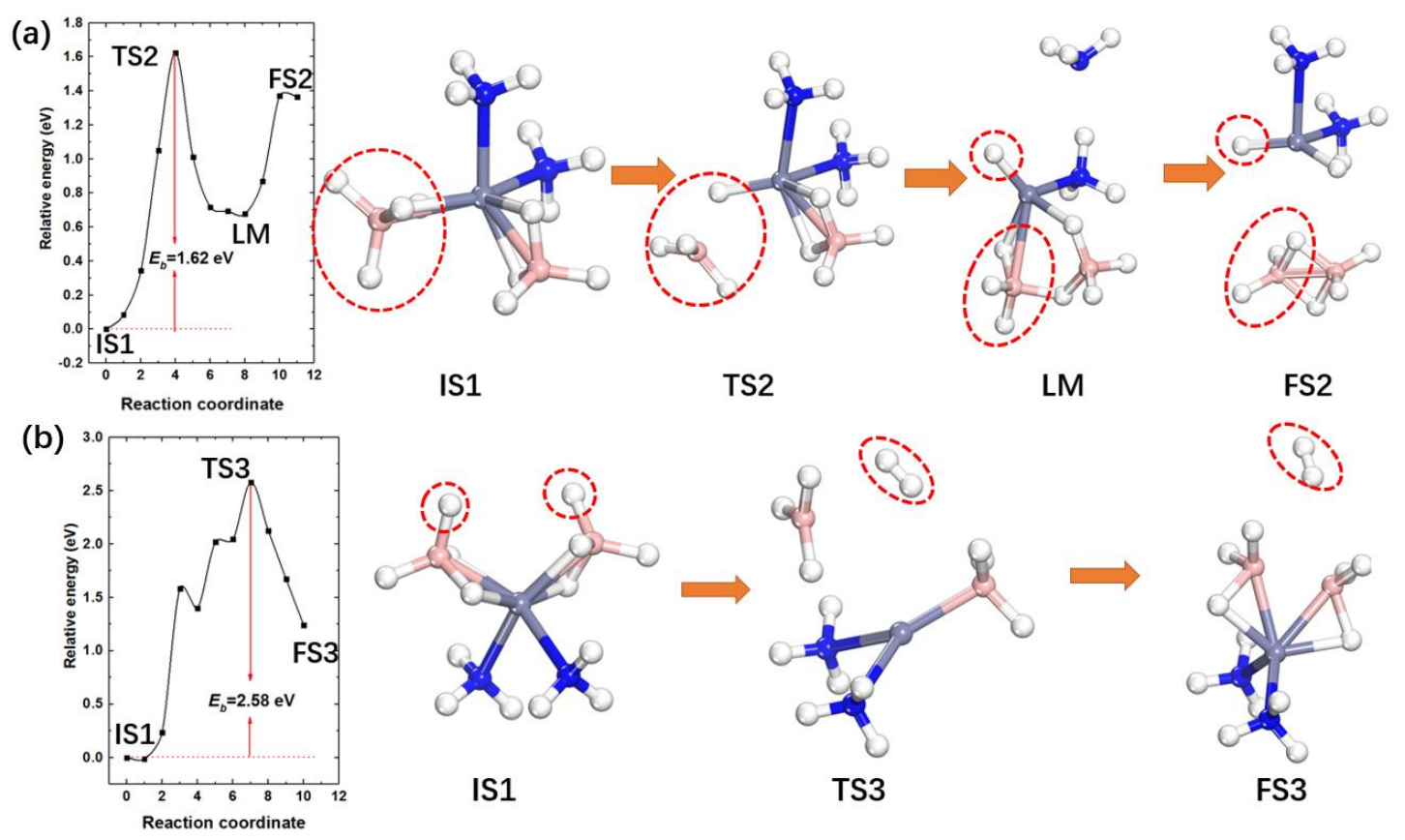

Figure 4. Calculated energy barrier, and initial (IS), transition (TS) and final (FS) geometric structures of (a) $\mathrm{B}_{2} \mathrm{H}_{6}$ formation and (b) $\mathrm{BH}_{3}$ formation. $E_{b}$ represents the calculated energy barrier.

We first calculated the formation of $\mathrm{B}_{2} \mathrm{H}_{6}$ via combination of two $\mathrm{BH}_{3}$ from $\left[\mathrm{BH}_{4}\right]^{-}$with two remaining hydrides bonding to the Zn cation. This reaction pathway was simplified as the following equation:

$2 \mathrm{BH}_{4}{ }^{-} \rightarrow \mathrm{B}_{2} \mathrm{H}_{6}+2 \mathrm{H}^{-}$

As shown in Figure 4a, the CI-NEB energy profile indicates that $\left[\mathrm{Zn}\left(\mathrm{NH}_{3}\right)_{2}\right]\left[\mathrm{BH}_{4}\right]_{2}$ first overcomes an energy barrier of $1.62 \mathrm{eV}$ to form a local minimize configuration with $\mathrm{B}_{2} \mathrm{H}_{7}-$-like anion fragment (LM as shown in Figure 4a). The $\mathrm{B}_{2} \mathrm{H}_{7}{ }^{-}$-like anion fragment subsequently transforms to $\mathrm{B}_{2} \mathrm{H}_{6}$ through an endothermal process with a reaction enthalpy of $0.68 \mathrm{eV}$. This indicates that $\mathrm{B}_{2} \mathrm{H}_{6}$ formation via $\mathrm{LM} \rightarrow \mathrm{FS} 2$ is kinetically and thermodynamically unfavorable because the reverse reaction to form $\mathrm{B}_{2} \mathrm{H}_{7}{ }^{-}$-like anion fragment $(\mathrm{FS} 2 \rightarrow \mathrm{LM})$ is a barrierless exothermal process.

We also examined the pathway in which two hydrides from $\mathrm{BH}_{4}{ }^{-}$directly combine with 
each other to form $\mathrm{H}_{2}$, and the two remaining $\mathrm{BH}_{3}$ fragments bond to the $\mathrm{Zn}$ cation. This reaction pathway was simplified as the following equation:

$2 \mathrm{BH}_{4}{ }^{-}+\mathrm{Zn}^{2+} \rightarrow \mathrm{Zn}\left(\mathrm{BH}_{3}\right)_{2}+\mathrm{H}_{2}$

As shown in Figure 4b, the final configuration (FS3) shows that two $\mathrm{BH}_{3}$ bond to the $\mathrm{Zn}$

cation with $\mathrm{Zn}-\mathrm{B}$ and B-B distances of 2.072 and $1.932 \AA$, respectively. This process is also an endothermal process with the reaction enthalpy and barrier of 1.23 and $2.58 \mathrm{eV}$, respectively. The high reaction barrier indicates that this process is kinetically unfavorable.

The above discussion indicates that the formation of $\mathrm{B}_{2} \mathrm{H}_{6}$ and $\mathrm{BH}_{3}$ is kinetically and/or thermodynamically unfavorable, in consistent with experimental results that not boranes were detected during decomposition of $\left[\mathrm{Zn}\left(\mathrm{NH}_{3}\right)_{2}\right]\left[\mathrm{BH}_{4}\right]_{2}{ }^{22}$

\subsection{Formation of the $\mathrm{B}_{2} \mathrm{H}_{7}^{-}$Intermediate}

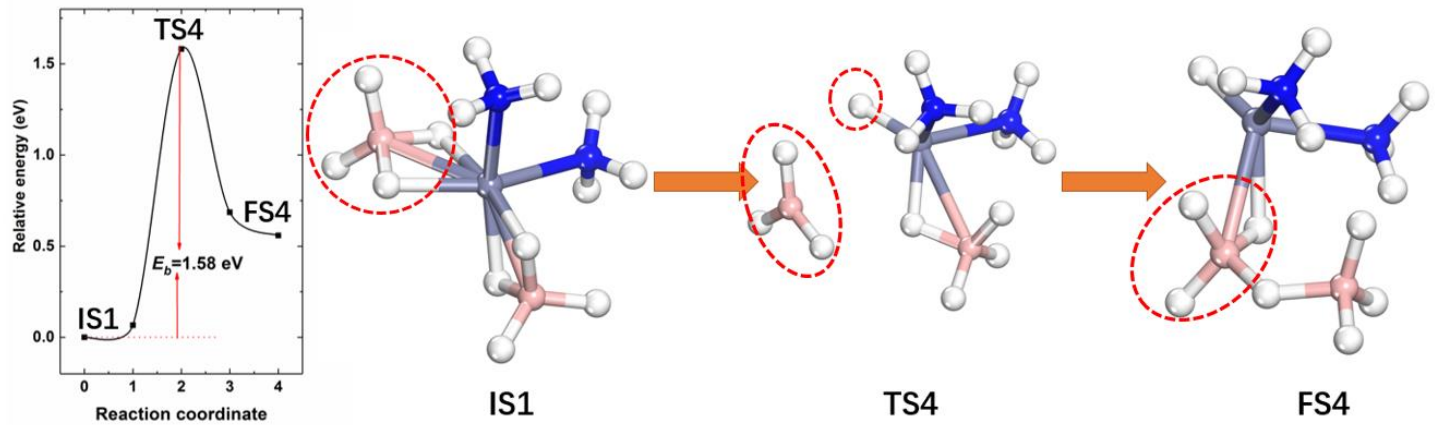

Figure 5.Calculated energy barrier, and initial (IS), transition (TS) and final (FS) geometric structures of $\mathrm{B}_{2} \mathrm{H}_{7}{ }^{-}$formation. $E_{b}$ represents the calculated energy barrier.

We further calculated the formation of $\mathrm{B}_{2} \mathrm{H}_{7}{ }^{-}$intermediate via the combination of two $\mathrm{BH}_{4}{ }^{-}$with a remaining hydride bonding to the $\mathrm{Zn}$ cation. This reaction pathway was simplified as the following equation:

$2 \mathrm{BH}_{4}^{-} \rightarrow \mathrm{B}_{2} \mathrm{H}_{7}^{-}+\mathrm{H}^{-}$

As shown in Figure 5, the formation of the $\mathrm{B}_{2} \mathrm{H}_{7}{ }^{-}$intermediate through IS1 $\rightarrow$ TS4 $\rightarrow \mathrm{FS} 4$ 
is an endothermal process with reaction enthalpy and barrier of $0.56 \mathrm{eV}(0.62 \mathrm{eV}$ at 300 $\mathrm{K})$ and $1.58 \mathrm{eV}(1.52 \mathrm{eV}$ including zero-point energy correction), respectively. The geometry of TS4 shows that a hydride from $\mathrm{BH}_{4}{ }^{-}$migrates and ultimately bonds to $\mathrm{Zn}$ cation with a Zn-H distance of $\sim 1.56 \AA$, which is $0.33 \AA$ shorter than $\mathrm{Zn}-\mathrm{H}$ distances in crystalline phase of $\left[\mathrm{Zn}\left(\mathrm{NH}_{3}\right)_{2}\right]\left[\mathrm{BH}_{4}\right]_{2} .{ }^{22}$ Thus, the $\mathrm{Zn}$ cation assists the formation of $\mathrm{B}_{2} \mathrm{H}_{7}{ }^{-}$intermediate by extracting a hydride from $\mathrm{BH}_{4}^{-}$to form $\mathrm{Zn}-\mathrm{H}$ ionic bond. Compared to that of $\mathrm{H}_{2}$ release via combining a hydride from $\mathrm{BH}_{4}{ }^{-}$and a proton from $\mathrm{NH}_{3}\left(\mathrm{BH}_{4}{ }^{-}+\mathrm{NH}_{3} \rightarrow \mathrm{BH}_{3} \mathrm{NH}_{2}{ }^{-}+\mathrm{H}_{2}\right.$, IS $\rightarrow \mathrm{TS} \rightarrow \mathrm{FS}$ as shown in Figure 2), the formation of $\mathrm{B}_{2} \mathrm{H}_{7}^{-}$intermediate is $0.44 \mathrm{eV}$ lower in energy barrier. This indicates that $\left[\mathrm{Zn}\left(\mathrm{NH}_{3}\right)_{2}\right]\left[\mathrm{BH}_{4}\right]_{2}$ may first undergo a phase transformation to form $\mathrm{B}_{2} \mathrm{H}_{7}{ }^{-}$rather than directly release $\mathrm{H}_{2}$ upon heating.

\subsection{Formation of $\mathrm{NH}_{3} \mathrm{BH}_{3}$ Intermediate}

(a)

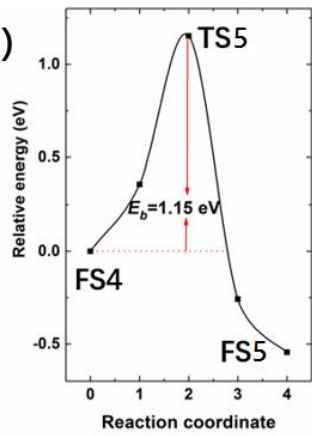

(b)

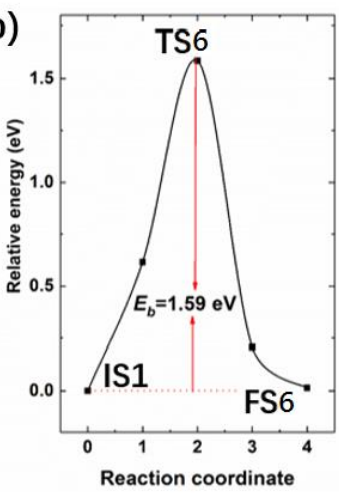

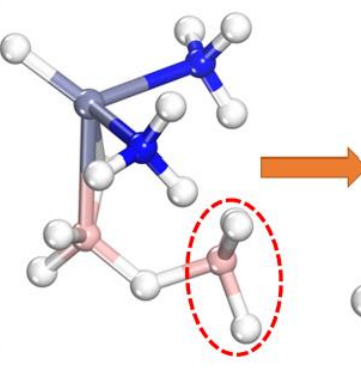

FS4

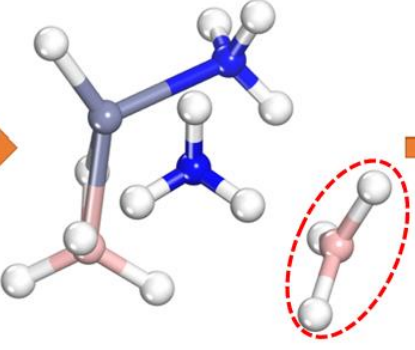

TS5

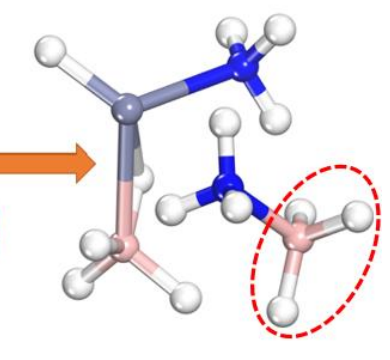

FS5

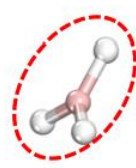

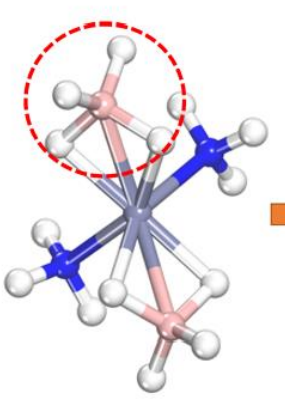

IS1

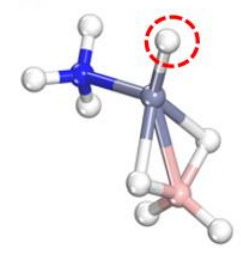

TS6

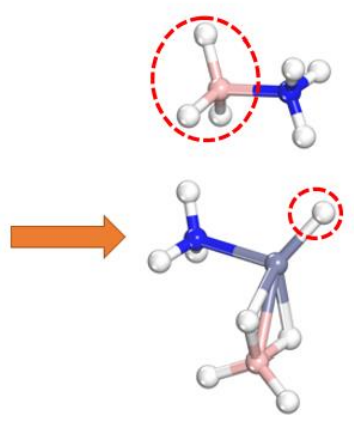

FS6

Figure 6. Calculated energy barrier, and initial (IS), transition (TS) and final (FS) geometric structure of $\mathrm{NH}_{3} \mathrm{BH}_{3}$ formation via (a) combining $\mathrm{BH}_{3}$ from $\mathrm{B}_{2} \mathrm{H}_{7}^{-}$with $\mathrm{NH}_{3}$ (b) 
combining $\mathrm{BH}_{3}$ from $\mathrm{BH}_{4}{ }^{-}$with $\mathrm{NH}_{3} . E_{b}$ represents the calculated energy barrier.

A previous study suggests that $\mathrm{B}_{2} \mathrm{H}_{7}^{-}$would combine with $\mathrm{NH}_{3}$ to form $\mathrm{NH}_{3} \mathrm{BH}_{3}$ and $\mathrm{BH}_{4}{ }^{-}$ in gas phase. ${ }^{37}$ It would be interesting to examine whether or not this process can occur in $\left[\mathrm{Zn}\left(\mathrm{NH}_{3}\right)_{2}\right]\left[\mathrm{BH}_{4}\right]_{2}$. As shown in Figure 6a, we calculated the rearrangement pathway in which a $\mathrm{BH}_{3}$ from $\mathrm{B}_{2} \mathrm{H}_{7}{ }^{-}$combines with a $\mathrm{NH}_{3}$ to form $\mathrm{NH}_{3} \mathrm{BH}_{3}$ and $\mathrm{BH}_{4}{ }^{-}$fragments through FS4 $\rightarrow$ TS5 $\rightarrow$ FS5. The reaction pathway was simplified as the following equation:

$\mathrm{B}_{2} \mathrm{H}_{7}^{-}+\mathrm{NH}_{3} \rightarrow \mathrm{BH}_{4}^{-}+\mathrm{NH}_{3} \mathrm{BH}_{3}$

This rearrangement is an exothermal process with a reaction barrier of $1.15 \mathrm{eV}(1.30 \mathrm{eV}$ including zero-point energy correction). To take the rearrangement enthalpy from $\mathrm{BH}_{4}{ }^{-}$to $\mathrm{B}_{2} \mathrm{H}_{7}{ }^{-}$into account, the effective barrier for $\mathrm{NH}_{3} \mathrm{BH}_{3}$ formation via $\mathrm{IS} 1 \rightarrow \mathrm{TS} 4 \rightarrow \mathrm{FS} 4 \rightarrow \mathrm{TS} 5 \rightarrow \mathrm{FS} 5 \quad$ is $1.71 \mathrm{eV} \quad(1.93 \mathrm{eV}$ including zero-point energy correction).

An alternative pathway to form the $\mathrm{NH}_{3} \mathrm{BH}_{3}$ intermediate can be achieved through combination of a $\mathrm{BH}_{3}$ from $\mathrm{BH}_{4}^{-}$and a $\mathrm{NH}_{3}$ in $\left[\mathrm{Zn}\left(\mathrm{NH}_{3}\right)_{2}\right]\left[\mathrm{BH}_{4}\right]_{2}$, with a remaining hydride bonding to the $\mathrm{Zn}$ cation (Figure $6 \mathrm{~b}$ ). This reaction pathway was simplified as the following equation:

$\mathrm{BH}_{4}{ }^{-}+\mathrm{NH}_{3} \rightarrow \mathrm{NH}_{3} \mathrm{BH}_{3}+\mathrm{H}^{-}$

As shown in Figure 6b, the geometry of TS6 shows that the Zn cation assists the formation of the $\mathrm{NH}_{3} \mathrm{BH}_{3}$ intermediate by extracting a hydride from $\mathrm{BH}_{4}{ }^{-}$to form the $\mathrm{Zn}-\mathrm{H}$ ionic bond. The $\mathrm{Zn}-\mathrm{H}$ distance in TS6 is $\sim 1.55 \AA$, similar to that in TS4. As shown in Figure 6b, the calculated energy barrier of direct formation of $\mathrm{NH}_{3} \mathrm{BH}_{3}$ intermediate via IS $1 \rightarrow$ TS6 $\rightarrow$ FS6 is $1.59 \mathrm{eV}$ (1.54 eV including zero-point energy correction), which is comparable to the formation of $\mathrm{B}_{2} \mathrm{H}_{7}{ }^{-}\left(2 \mathrm{BH}_{4}{ }^{-} \rightarrow \mathrm{B}_{2} \mathrm{H}_{7}{ }^{-}+\mathrm{H}^{-}, \mathrm{IS} 1 \rightarrow \mathrm{TS} 4 \rightarrow \mathrm{FS} 4\right.$ as shown in Figure 5). Therefore, the $\mathrm{NH}_{3} \mathrm{BH}_{3}$ and $\mathrm{B}_{2} \mathrm{H}_{7}{ }^{-}$intermediates may co-exist during the decomposition of $\left[\mathrm{Zn}\left(\mathrm{NH}_{3}\right)_{2}\right]\left[\mathrm{BH}_{4}\right]_{2}$. 


\subsection{Discussion}

Our above calculation compared the numbers of possible reaction pathways and indicated that the release of $\mathrm{B}_{2} \mathrm{H}_{6}$ and $\mathrm{BH}_{3}$ is kinetically and/or thermodynamically unfavorable for $\left[\mathrm{Zn}\left(\mathrm{NH}_{3}\right)_{2}\right]\left[\mathrm{BH}_{4}\right]_{2}$, in agreement with experimental results that no borane byproducts were detected during decomposition.

To better illustrate the decomposition mechanism of $\left[\mathrm{Zn}\left(\mathrm{NH}_{3}\right)_{2}\right]\left[\mathrm{BH}_{4}\right]_{2}$, the calculated reaction pathways with relatively low energy barriers including zero-point energy correction were summarized in Figure 7 and Table S1. As shown in Figure 7, our calculation results indicate the formation of $\mathrm{NH}_{3} \mathrm{BH}_{3}$ (via IS1 $\rightarrow$ TS6 $\rightarrow \mathrm{FS} 6$ ) and $\mathrm{B}_{2} \mathrm{H}_{7}{ }^{-}$ intermediates (via IS $1 \rightarrow \mathrm{TS} 4 \rightarrow \mathrm{FS} 4$ ) with comparable reaction barrier.

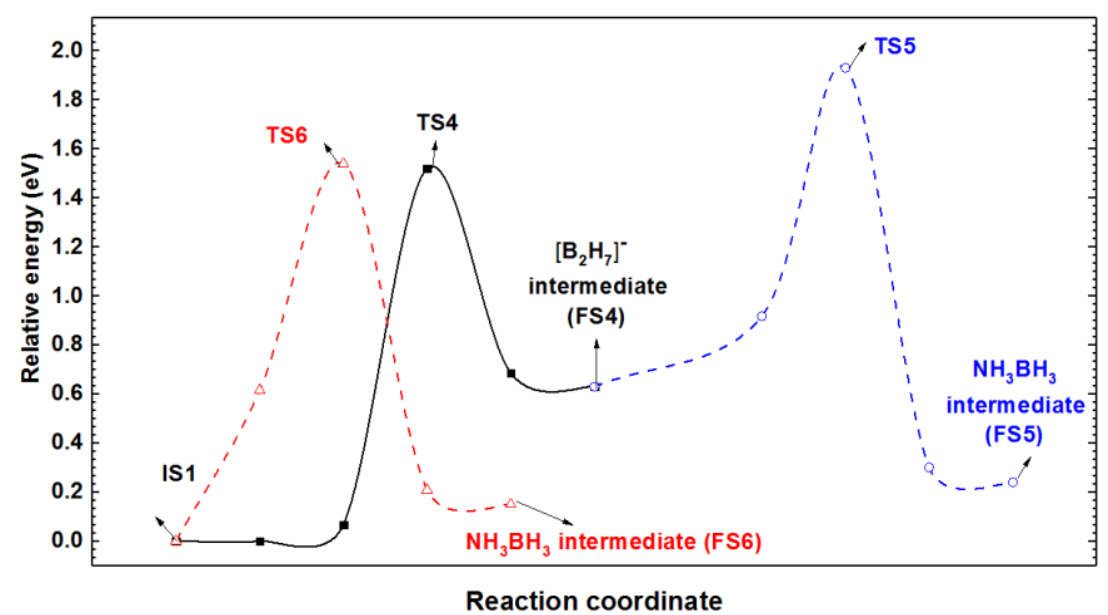

Figure 7 Energy profile of the formation of $\mathrm{NH}_{3} \mathrm{BH}_{3}$ and $\mathrm{B}_{2} \mathrm{H}_{7}^{-}$intermediates (including the zero-point energy correction). 

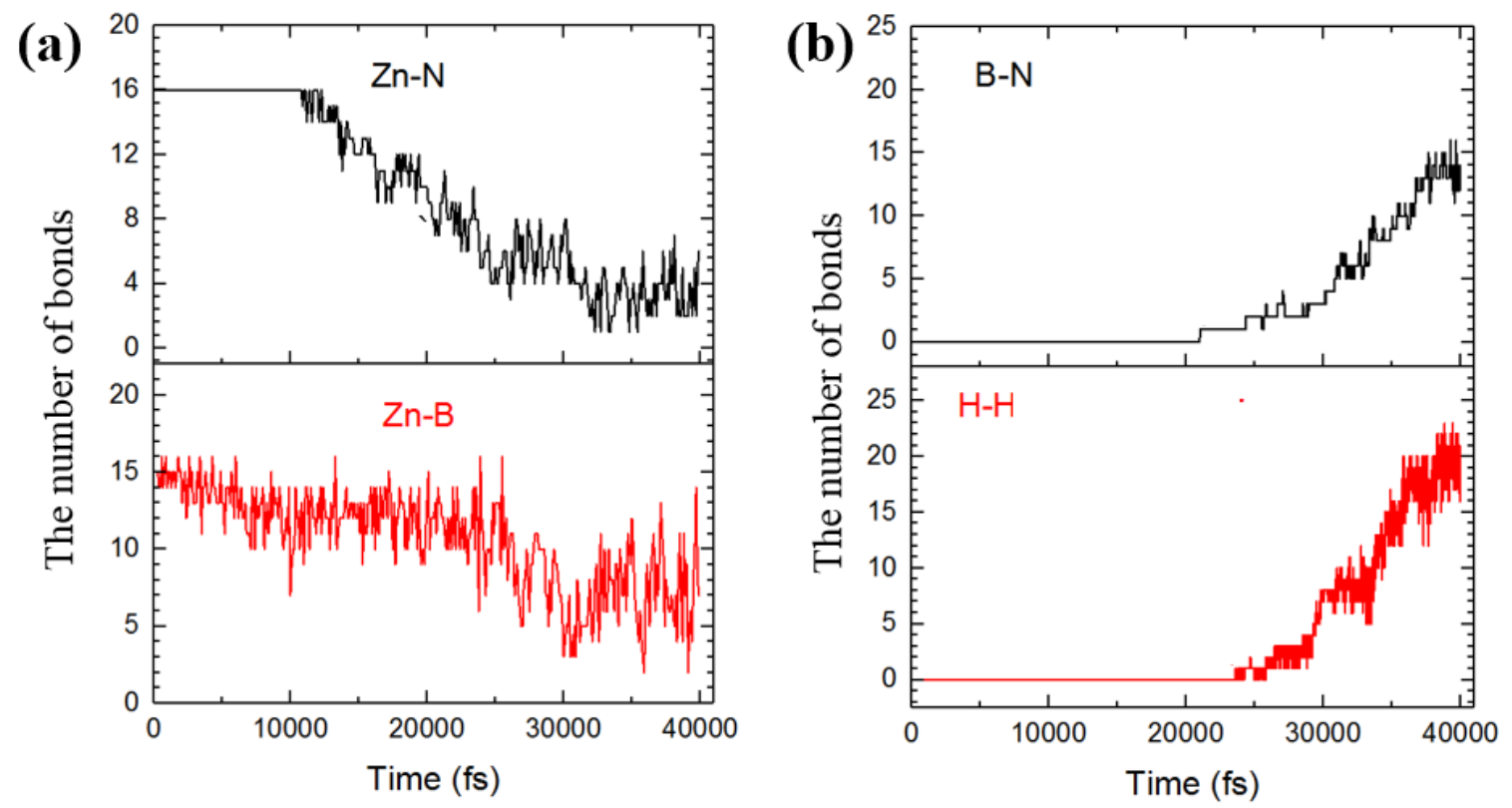

Figure 8. Bond number analysis for decomposition of $\left[\mathrm{Zn}\left(\mathrm{NH}_{3}\right)_{2}\right]\left[\mathrm{BH}_{4}\right]_{2}$.

To further examine the decomposition mechanism discussed above, AIMD simulation was performed using a $2 \times 1 \times 2$ supercell of $\left[\mathrm{Zn}\left(\mathrm{NH}_{3}\right)_{2}\right]\left[\mathrm{BH}_{4}\right]_{2}$ which contains 152 atoms. As shown in Figure 8a, from 0 to 10 ps (10 000 fs), the number of $\mathrm{Zn}-\mathrm{N}$ bonds remains unchanged, indicating that the $\mathrm{NH}_{3}$ molecules still coordinates with $\mathrm{Zn}$ cations. The number of $\mathrm{Zn}-\mathrm{B}$ bonds fluctuates from 16 to 10 because of the rotation of $\mathrm{BH}_{4}{ }^{-}$around $\mathrm{Zn}$ cations. With the simulation time increasing from 10 to $20 \mathrm{ps}$ (20 $000 \mathrm{fs}$ ), the number of $\mathrm{Zn}-\mathrm{N}$ bonds starts to decrease, indicating that some of $\mathrm{NH}_{3}$ molecules detach from $\mathrm{Zn}$ cations. Figure $8 \mathrm{~b}$ shows that the number of $\mathrm{N}-\mathrm{B}$ and $\mathrm{H}-\mathrm{H}$ bonds remains zero before 20 ps (20 $000 \mathrm{fs}$ ), suggesting that no N-B relative intermediates or $\mathrm{H}_{2}$ were formed. With the simulation time increasing from 20 to $40 \mathrm{ps}$ (40 $000 \mathrm{fs}$ ), the formation of N-B (started at $\sim 21000 \mathrm{fs}$ ) and $\mathrm{H}-\mathrm{H}$ bonds (started at $~ 24$ 000fs) were observed. 
(a)

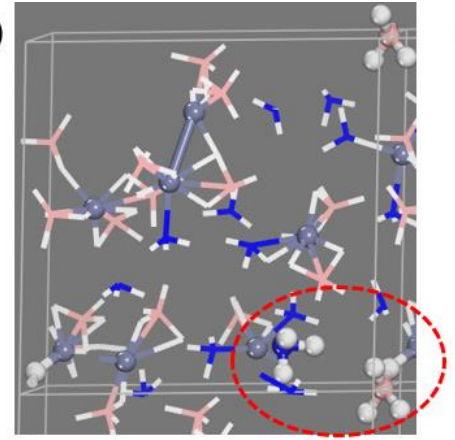

$20869 \mathrm{fs}$ (b)

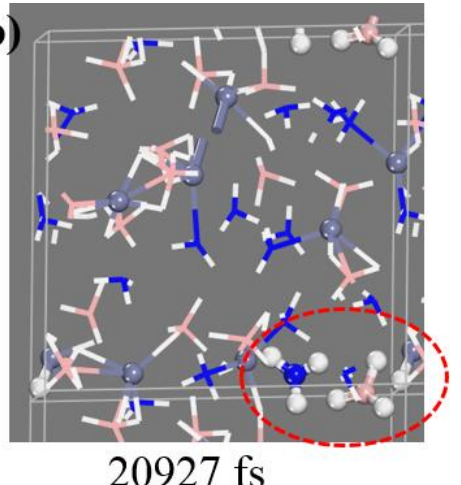

$20927 \mathrm{fs}$

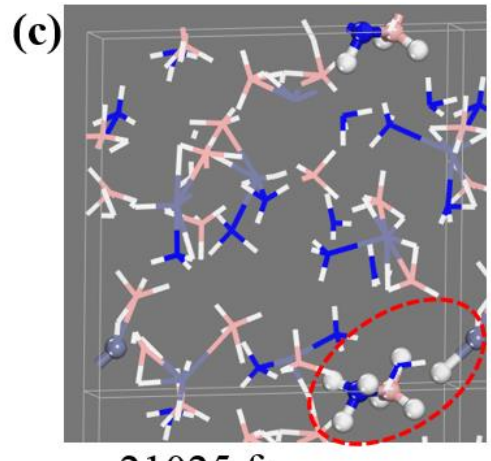

$21025 \mathrm{fs}$ (d)

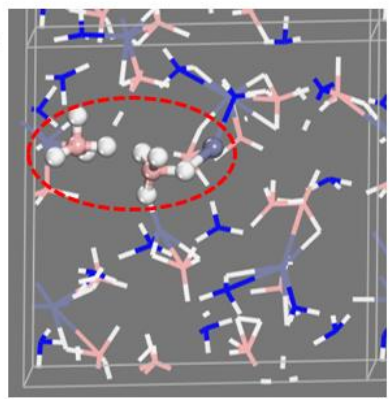

$24166 \mathrm{fs}$ (e)

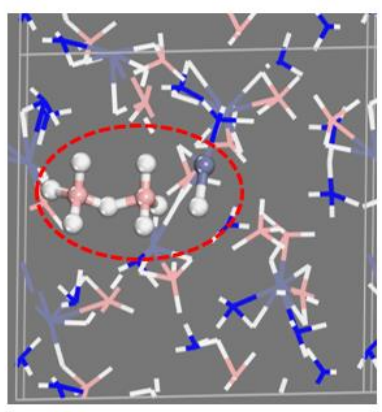

$24173 \mathrm{fs}$

Figure 9. Schematics of the formation of $\mathrm{NH}_{3} \mathrm{BH}_{3}$ (a-c) and $\mathrm{B}_{2} \mathrm{H}_{7}{ }^{-}$(d-e) observed in our AIMD simulations. The intermediates are highlighted as ball and stick, other atoms are represent as line.

The MD trajectories in Figure 9a-9c show the formation of the $\mathrm{NH}_{3} \mathrm{BH}_{3}$ intermediate via combination of $\mathrm{NH}_{3}$ and $\mathrm{BH}_{4}^{-}$with a remainder $\mathrm{H}^{-}$bonding to the $\mathrm{Zn}$ cation from simulation time of 20869 fs to 21025 fs. As shown in Figure 9d and 9e, two $\mathrm{BH}_{4}^{-}$ combine to form $\mathrm{B}_{2} \mathrm{H}_{7}{ }^{-}$from the simulation time of $24166 \mathrm{fs}$ to $24173 \mathrm{fs}$. The above MD calculation results indicate that the $\mathrm{Zn}$ cation assists the formation of $\mathrm{NH}_{3} \mathrm{BH}_{3}$ and $\mathrm{B}_{2} \mathrm{H}_{7}^{-}$ intermediates by extracting a hydride from $\mathrm{BH}_{4}{ }^{-}$to form the $\mathrm{Zn}-\mathrm{H}$ ionic bond, in consistent with our above CI-NEB calculation results. 
(a)

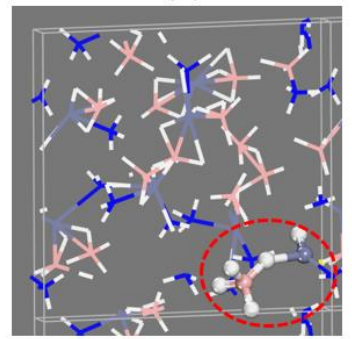

23531 fs (b)

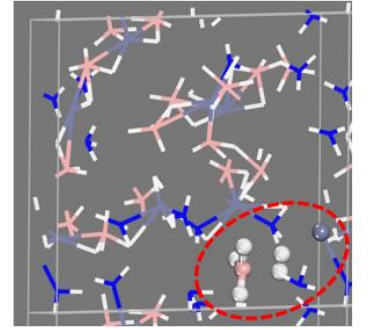

23755 fs (c)

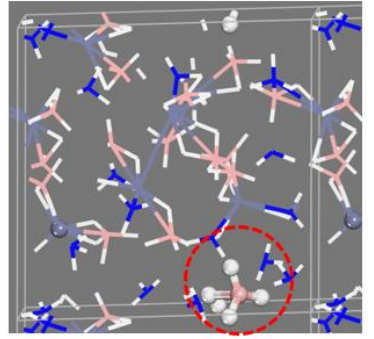

23935 fs (d)

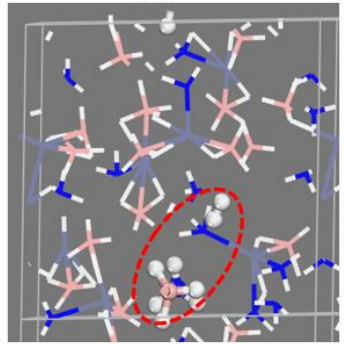

24387 fs

Figure 10. Schematics of the release of $\mathrm{H}_{2}$ observed in our AIMD simulations. The intermediates are highlighted as ball-and-stick models, and the other atoms are represent as line.

The MD trajectories show two initial dehydrogenation pathways as presented in Figure 10 and 11. As discussed above, the $\mathrm{Zn}$ cation extracts a hydride from $\mathrm{BH}_{4}{ }^{-}$to facilitate the formation of $\mathrm{NH}_{3} \mathrm{BH}_{3}$ and $\mathrm{B}_{2} \mathrm{H}_{7}-$ intermediates. Figure 10a-10c shows that the extra hydride on $\mathrm{Zn}$ cation transfers to the neighboring $\mathrm{BH}_{4}{ }^{-}$with the formation of $\mathrm{BH}_{3}-\mathrm{H}_{2}$ intermediate. $\mathrm{BH}_{3}-\mathrm{H}_{2}$ intermediate further combines with $\mathrm{NH}_{3}$ to form $\mathrm{H}_{2}$ and $\mathrm{NH}_{3} \mathrm{BH}_{3}$ (Figure 10d). The simplied reaction pathways were summarized as following:

$\mathrm{Zn}^{2+}+\mathrm{H}^{-}+\mathrm{BH}_{4}^{-} \rightarrow \mathrm{Zn}+\mathrm{BH}_{3}-\mathrm{H}_{2}$

$\mathrm{BH}_{3}-\mathrm{H}_{2}+\mathrm{NH}_{3} \rightarrow \mathrm{H}_{2}+\mathrm{NH}_{3} \mathrm{BH}_{3}$ 
(a)

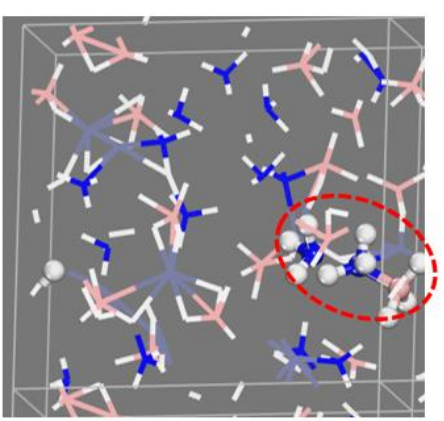

27331 fs (b)

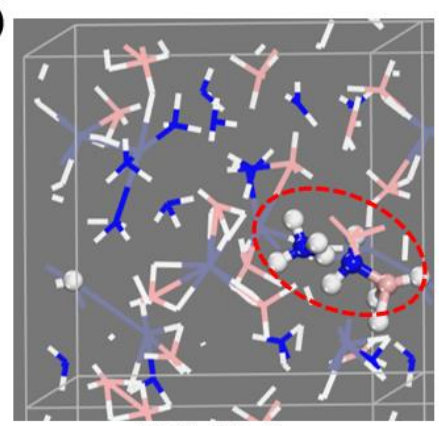

27364 fs (c)

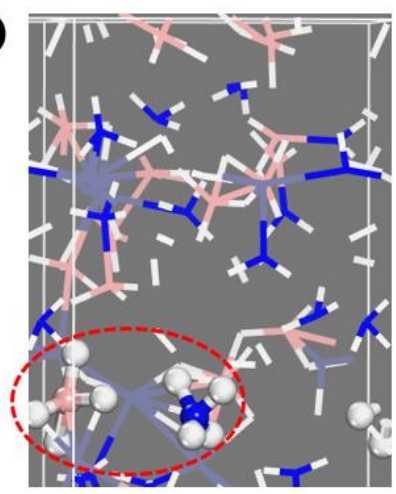

29600 fs (d)

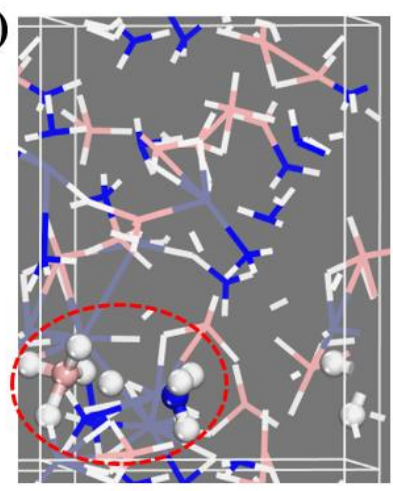

29733 fs (e)

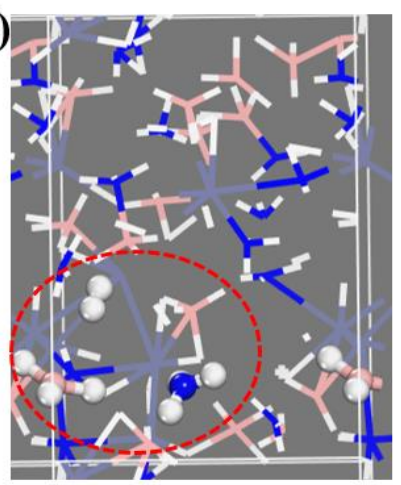

29820 fs

Figure 11. Schematics of the formation of $\mathrm{NH}_{4}{ }^{+}(\mathrm{a}-\mathrm{b})$ and release of $\mathrm{H}_{2}$ (c-e) observed in our AIMD simulations. The intermediates are highlighted as ball and stick, other atoms are represent as line.

As shown in Figure 11a and $11 \mathrm{~b}$, the formation of $\mathrm{NH}_{3} \mathrm{BH}_{3}$ facilitates the $\mathrm{H}_{2}$ release by transferring a proton from $\mathrm{NH}_{3} \mathrm{BH}_{3}$ intermediate to $\mathrm{NH}_{3}$, with the formation of $\mathrm{NH}_{4}{ }^{+}$and $\mathrm{NH}_{2} \mathrm{BH}_{3}{ }^{-}$. The $\mathrm{NH}_{2} \mathrm{BH}_{3}{ }^{-}$fragment further rotates and bonds to the vicinal $\mathrm{Zn}$ cation. The $\mathrm{NH}_{4}{ }^{+}$fragment migrates and combines with a $\mathrm{BH}_{4}{ }^{-}$to form $\mathrm{H}_{2}, \mathrm{NH}_{3}$ and $\mathrm{BH}_{3}$ as shown in Figure 11c-11e.

The simplified reaction pathways were summarized as following:

$\mathrm{NH}_{3} \mathrm{BH}_{3}+\mathrm{NH}_{3} \rightarrow \mathrm{NH}_{2} \mathrm{BH}_{3}^{-}+\mathrm{NH}_{4}^{+}$

$\mathrm{NH}_{4}{ }^{+}+\mathrm{BH}_{4}{ }^{-} \rightarrow \mathrm{H}_{2}+\mathrm{NH}_{3}+\mathrm{BH}_{3}$

The remaining $\mathrm{BH}_{3}$ fragment could combines with $\mathrm{NH}_{3}$ to form $\mathrm{NH}_{3} \mathrm{BH}_{3}$ or combine with $\mathrm{BH}_{4}^{-}$to form $\mathrm{B}_{2} \mathrm{H}_{7}^{-}$as discussed above. 


\section{Conclusions}

DFT calculation has been employed to investigate the decomposition mechanism of $\left[\mathrm{Zn}\left(\mathrm{NH}_{3}\right)_{2}\right]\left[\mathrm{BH}_{4}\right]_{2}$. Our calculation indicates that the formation of $\mathrm{B}_{2} \mathrm{H}_{6}$ and $\mathrm{BH}_{3}$ is kinetically and/or thermodynamically unfavorable for $\left[\mathrm{Zn}\left(\mathrm{NH}_{3}\right)_{2}\right]\left[\mathrm{BH}_{4}\right]_{2}$, which explains the experimental observation that no $\mathrm{B}_{2} \mathrm{H}_{6}$ or $\mathrm{BH}_{3}$ byproducts were detected during thermal decomposition. On the other hand, our calculation indicates that the decomposition mechanism of $\left[\mathrm{Zn}\left(\mathrm{NH}_{3}\right)_{2}\right]\left[\mathrm{BH}_{4}\right]_{2}$ is different from those of other reported AMBs, which releases $\mathrm{H}_{2}$ via directly combining hydrides from $\mathrm{BH}_{4}{ }^{-}$and protons from $\mathrm{NH}_{3}$. The $\left[\mathrm{Zn}\left(\mathrm{NH}_{3}\right)_{2}\right]\left[\mathrm{BH}_{4}\right]_{2}$ is able to form $\mathrm{NH}_{3} \mathrm{BH}_{3}$ and $\mathrm{B}_{2} \mathrm{H}_{7}^{-}$intermediates during decomposition. The $\mathrm{Zn}$ cation assists the formation of $\mathrm{NH}_{3} \mathrm{BH}_{3}$ and $\mathrm{B}_{2} \mathrm{H}_{7}{ }^{-}$intermediates by extracting a hydride from $\mathrm{BH}_{4}{ }^{-}$to form the $\mathrm{Zn}-\mathrm{H}$ ionic bond. Our calculation also indicates that the dehydrogenation occurs through the following two reaction pathways: transfer of a hydride from the $\mathrm{Zn}$ cation to $\mathrm{BH}_{4}{ }^{-}$with the formation of $\mathrm{BH}_{3}-\mathrm{H}_{2}$, which further combines with $\mathrm{NH}_{3}$ to form $\mathrm{H}_{2}$ and $\mathrm{NH}_{3} \mathrm{BH}_{3}$ and transfer of a proton from $\mathrm{NH}_{3} \mathrm{BH}_{3}$ to $\mathrm{NH}_{3}$ with the formation of $\mathrm{NH}_{4}^{+}$, which combines with $\mathrm{BH}_{4}{ }^{-}$to release hydrogen. We hope that our findings may provide useful insights for improving the dehydrogenation properties of $\left[\mathrm{Zn}\left(\mathrm{NH}_{3}\right)_{2}\right]\left[\mathrm{BH}_{4}\right]_{2}$ as well as offer guidelines for designing novel $\mathrm{Zn}$-based ammine borohydrides for hydrogen storage.

\section{Conflicts of interest}

There are no conflicts to declare

\section{Supporting Information}

Calculated reaction pathways of $\left[\mathrm{Zn}\left(\mathrm{NH}_{3}\right)_{2}\right]\left[\mathrm{BH}_{4}\right]_{2}$ with relatively low energy barriers including zero-point energy correction.

\section{Acknowledgements}

This work is supported by the National Natural Science Foundation of China (51601068, 51625102, 51471053), Natural Science Foundation of Fujian Province (2016J05129). 


\section{References}

1. Chen, P.; Xiong, Z. T.; Luo, J. Z.; Lin, J. Y.; Tan, K. L., Interaction of hydrogen with metal nitrides and imides. Nature 2002, 420, 302-304.

2. Schlapbach, L.; Züttel, A., Hydrogen-storage materials for mobile applications. Nature 2001, 414, 353-358.

3. Xiong, Z.; Yong, C. K.; Wu, G.; Chen, P.; Shaw, W.; Karkamkar, A.; Autrey, T.; Jones, M. O.; Johnson, S. R.; Edwards, P. P., High-capacity hydrogen storage in lithium and sodium amidoboranes. Nature Materials 2008, 7, 138-141.

4. Orimo, S.; Nakamori, Y.; Eliseo, J. R.; Zuttel, A.; Jensen, C. M., Complex hydrides for hydrogen storage. Chem. Rev. 2007, 107, 4111-4132.

5. Paskevicius, M.; Jepsen, L. H.; Schouwink, P.; Cerny, R.; Ravnsbaek, D. B.; Filinchuk, Y.; Dornheim, M.; Besenbacher, F.; Jensen, T. R., Metal borohydrides and derivatives - synthesis, structure and properties. Chem. Soc. Rev. 2017, 46, 1565-1634.

6. Li, H.-W.; Yan, Y.; Orimo, S.-i.; Züttel, A.; Jensen, C. M., Recent progress in metal borohydrides for hydrogen storage. Energies 2011, 4, 185-214.

7. George, L.; Saxena, S. K., Structural stability of metal hydrides, alanates and borohydrides of alkali and alkali-earth elements: a review. Int. J. Hydrogen Energy 2010, $35,5454-5470$.

8. Dovgaliuk, I.; Filinchuk, Y., Aluminium complexes of B- and N-based hydrides: Synthesis, structures and hydrogen storage properties. Int. J. Hydrogen Energy 2016, 41, 15489-15504.

9. Li, H. W.; Orimo, S.; Nakamori, Y.; Miwa, K.; Ohba, N.; Towata, S.; Züttel, A., Materials designing of metal borohydrides: viewpoints from thermodynamical stabilities. J. Alloys Compd. 2007, 446, 315-318.

10. Nakamori, Y.; Miwa, K.; Ninomiya, A.; Li, H.; Ohba, N.; Towata, S.; Züttel, A.; Orimo, S., Correlation between thermodynamical stabilities of metal borohydrides and 
cation electronegativites: first-principles calculations and experiments. Phys. Rev. B 2006, $74,045126$.

11. Huang, M.; Zhong, H.; Ouyang, L.; Peng, C.; Zhu, X.; Zhu, W.; Fang, F.; Zhu, M. Efficient regeneration of sodium borohydride via ball milling dihydrate sodium metaborate with magnesium and magnesium silicide. J. Alloys Compd. 2017, 729, 1079-1085.

12. Chłopek, K.; Frommen, C.; Léon, A.; Zabara, O.; Fichtner, M., Synthesis and properties of magnesium tetrahydroborate, $\mathrm{Mg}\left(\mathrm{BH}_{4}\right)_{2}$. J. Mater. Chem. 2007, 17, 3496-3503.

13. Yan, Y.; Remhof, A.; Hwang, S.; Li, H.; Mauron, P.; Orimo, S.; Zuttel, A., Pressure and temperature dependence of the decomposition pathway of $\mathrm{LiBH}_{4}$. Phys. Chem. Chem. Phys. 2012, 14, 6514-6519.

14. Ouyang, L.; Chen, W.; Liu, J.; Felderhoff, M.; Wang, H.; Zhu, M. Enhancing the regeneration process of consumed $\mathrm{NaBH}_{4}$ for hydrogen storage. Adv. Energy Mater. 2017, 7, 1700299

15. Nakamori, Y.; Li, H. W.; Matsuo, M.; Miwa, K.; Towata, S.; Orimo, S., Development of metal borohydrides for hydrogen storage. J. Phys. Chem. Solids 2008, 69, 2292-2296.

16. Jeon, E.; Cho, Y. W., Mechanochemical synthesis and thermal decomposition of zinc borohydride. J. Alloys Compd. 2006, 422, 273-275.

17. Guo, Y. H.; Xia, G. L.; Zhu, Y.; Gao, L.; Yu, X. B., Hydrogen release from amminelithium borohydride, $\mathrm{LiBH}_{4} \cdot \mathrm{NH}_{3}$. Chem. Commun. 2010, 46, 2599-2601.

18. Guo, Y. H.; Jiang, Y. X.; Xia, G. L.; Yu, X. B., Ammine aluminium borohydrides: an appealing system releasing over $12 \mathrm{wt} \%$ pure $\mathrm{H}_{2}$ under moderate temperature. Chem. Commun. 2012, 48, 4408-4410.

19. Chu, H.; Wu, G.; Xiong, Z.; Guo, J.; He, T.; Chen, P., Structure and hydrogen storage properties of calcium borohydride diammoniate. Chem. Mater. 2010, 22, 6021-6028.

20. Wang, K.; Zhang, J.-G.; Lang, X.-Q. The mechanism of controllable 
dehydrogenation: CPMD study of $\mathrm{M}\left(\mathrm{BH}_{4}\right)_{\mathrm{x}}\left(\mathrm{NH}_{3}\right)_{\mathrm{y}}(\mathrm{M}=\mathrm{Li}, \mathrm{Mg})$ decomposition. Phys. Chem. Chem. Phys. 2016, 18 (10), 7015-7018.

21. Johnson, S. R.; David, W. I. F.; Royse, D. M.; Sommariva, M.; Tang, C. Y.; Fabbiani, F.; Jones, M. O.; Edwards, P. P., The monoammoniate of lithium borohydride, $\mathrm{Li}\left(\mathrm{NH}_{3}\right) \mathrm{BH}_{4}$ : an effective ammonia storage compound. Chem. -Eur. J. 2009, 4, 849-854. 22. Gu, Q. F.; Gao, L.; Guo, Y. H.; Tan, Y. B.; Tang, Z. W.; Wallwork, K. S.; Zhang, F. W.; Yu, X. B., Structure and decomposition of zinc borohydride ammonia adduct: towards a pure hydrogen release. Energy Environ. Sci. 2012, 5, 7590-7600.

23. Soloveichik, G.; Her, J. H.; Stephens, P. W.; Gao, Y.; Rijssenbeek, J.; Andrus, M.; Zhao, J. C., Ammine magnesium borohydride complex as a new material for hydrogen storage: structure and properties of $\mathrm{Mg}\left(\mathrm{BH}_{4}\right)_{2} 2 \mathrm{NH}_{3}$. Inorg. Chem. 2008, 47, 4290-4298. 24. Wang, K.; Zhang, J.-G.; Jiao, J.-S.; Zhang, T.; Zhou, Z.-N. A first-principles study: structure and decomposition of mono-/bimetallic ammine borohydrides. J. Phys. Chem. C 2014, $118,8271-8279$

25. Chen, X. W.; Yuan, F.; Tan, Y. B.; Tang, Z. W.; Yu, X. B., Improved dehydrogenation properties of $\mathrm{Ca}\left(\mathrm{BH}_{4}\right)_{2} n \mathrm{NH}_{3}\left(\mathrm{n}=1,2\right.$, and 4) combined with $\mathrm{Mg}\left(\mathrm{BH}_{4}\right)_{2}$. J. Phys. Chem. C 2012, 116, 21162-21168.

26. Guo, Y. H.; Wu, H.; Zhou, W.; Yu, X. B., Dehydrogenation tuning of ammine borohydrides using double-metal cations. J. Am. Chem. Soc. 2011, 133, 4690-4693.

27. Wang, M.; Ouyang, L.; Peng, C.; Zhu, X.; Zhu, W.; Shao, H.; Zhu, M. Synthesis and hydrolysis of $\mathrm{NaZn}\left(\mathrm{BH}_{4}\right)_{3}$ and its ammoniates. J. Mater. Chem. A 2017, 5 (32), 17012-17020.

28. Wu, D.; Ouyang, L.; Liu, J.; Wang, H.; Shao, H.; Zhu, M. Hydrogen generation properties and the hydrolysis mechanism of $\mathrm{Zr}\left(\mathrm{BH}_{4}\right)_{4} \cdot 8 \mathrm{NH}_{3}$. J. Mater. Chem. A 2017, 5 (32), 16630-16635.

29. Gradišek, A.; Jepsen, L. H.; Jensen, T. R.; Conradi, M. S. Nuclear magnetic resonance study of molecular dynamics in ammine metal borohydride $\operatorname{Sr}\left(\mathrm{BH}_{4}\right)_{2} \cdot\left(\mathrm{NH}_{3}\right)_{2} . J$. 
Phys. Chem. C 2016, 120, 24646-24654.

30. Emdadi, A.; Demir, S.; Kışlak, Y.; Tekin, A. Computational screening of dual-cation metal ammine borohydrides by density functional theory. J. Phys. Chem. C 2016, 120, 13340-13350.

31. Huang, J.; Tan, Y.; Su, J.; Gu, Q.; Cerný, R.; Ouyang, L.; Sun, D.; Yu, X.; Zhu, M., Synthesis, structure and dehydrogenation of zirconium borohydride octaammoniate. Chem. Commun. 2015, 51, 2794-2797.

32. Huang, J. M.; Ouyang, L. Z.; Gu, Q. F.; Yu, X. B.; Zhu, M., Metal-borohydride-modified $\mathrm{Zr}\left(\mathrm{BH}_{4}\right)_{4} \cdot 8 \mathrm{NH}_{3}$ : low-temperature dehydrogenation yielding highly pure hydrogen. Chem.-Eur. J 2015, 21, 14931-14936.

33. Guo, Y. H.; Yu, X. B.; Sun, W. W.; Sun, D. L.; Yang, W. N., The hydrogen-enriched Al-B-N system as an advanced solid hydrogen-storage candidate. Angew. Chem. Int. Ed. 2011, 123, 1119-1123.

34. Chen, X.; Li, R.; Xia, G.; He, H.; Zhang, X.; Zou, W.; Yu, X., First-principles study of decomposition mechanisms of $\mathrm{Mg}\left(\mathrm{BH}_{4}\right)_{2} \cdot 2 \mathrm{NH}_{3}$ and $\operatorname{LiMg}\left(\mathrm{BH}_{4}\right)_{3} \cdot 2 \mathrm{NH}_{3}$. RSC Advances 2017, 7, 31027-31032.

35. Chen, X.; Li, R.; Xia, G.; He, H.; Zou, W.; Yu, X., A comparison study of decomposition mechanisms of single-cation and double-cations ( $\mathrm{Li}, \mathrm{Al}$ ) ammine borohydrides. Int. J. Hydrogen Energy 2017, 42, 24861-24867.

36. Sun, W. W.; Chen, X. W.; Gu, Q. F.; Wallwork, K. S.; Tan, Y. B.; Tang, Z. W.; Yu, X. B., A new ammine dual-cation (Li, Mg) borohydride: synthesis, structure, and dehydrogenation enhancement. Chem. -Eur. J. 2012, 18, 6825-6834.

37. Welchman, E.; Thonhauser, T., Decomposition mechanisms in metal borohydrides and their ammoniates. J. Mater. Chem. A 2017, 5, 4084-4092.

38. Kresse, G.; Furthmüller, J., Efficient iterative schemes for ab initio total-energy calculations using a plane-wave basis set. Phys. Rev. B 1996, 54, 11169.

39. Klimes, J.; Bowler, D. R.; Michaelides, A., Van der Waals density functionals applied 
to solids. Phys. Rev. B 2011, 83, 195131.

40. Klimes, J.; Bowler, D. R.; Michaelides, A., Chemical accuracy for the van der Waals density functional. J. Phys.: Condens. Matter 2009, 22, 022201.

41. Dion, M.; Rydberg, H.; Schroder, E.; Langreth, D. C.; Lundqvist, B. I., Van der Waals density functional for general geometries. Phys. Rev. Lett. 2004, 92, 246401.

42. Blöchl, P. E., Projector augmented-wave method. Phys. Rev. B 1994, 50, 17953.

43. Perdew, J. P.; Burke, K.; Ernzerhof, M., Generalized gradient approximation made simple. Phys. Rev. Lett. 1996, 77, 3865-3868.

44. Perdew, J. P.; Burke, K.; Wang, Y., Generalized gradient approximation for the exchange-correlation hole of a many-electron system. Phys. Rev. B 1996, 54, 16533-16539.

45. Monkhorst, H. J.; Pack, J. D., Special points for Brillouin-zone integrations. Phys. Rev. $B$ 1976, 13, 5188-5192.

46. Henkelman, G.; Uberuaga, B. P.; Jónsson, H., A climbing image nudged elastic band method for finding saddle points and minimum energy paths. J. Chem. Phy. 2000, 113, 9901-9904.

47. Henkelman, G.; Jónsson, H., Improved tangent estimate in the nudged elastic band method for finding minimum energy paths and saddle points. J. Chem. Phys. 2000, 113, 9978-9985. 


\section{TOC Graphic}

Formation of $\mathrm{NH}_{3} \mathrm{BH}_{3}$ Formation of $\mathrm{B}_{2} \mathrm{H}_{7}$
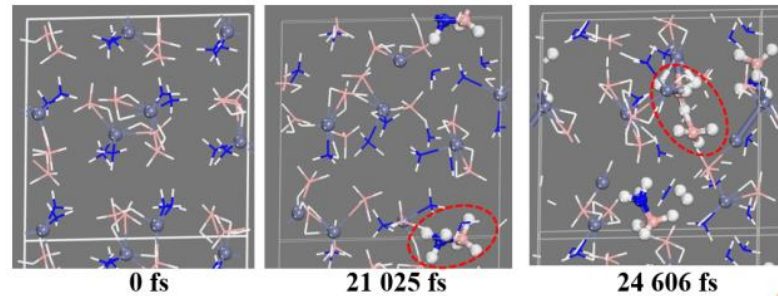

MD simulation times 